\title{
Joule per Kilogram
}

National Cancer Institute

\section{Source}

National Cancer Institute. Joule per Kilogram. NCI Thesaurus. Code C70439.

A unit of specific energy defined as the energy equal to one joule in the mass of matter equal to one kilogram. 